\title{
PENGARUH TAX AVOIDANCE DAN KEPEMILIKAN INSTITUSIONAL TERHADAP COST OF DEPT PADA PERUSAHAAN MAKANAN DAN MINUMAN
}

\author{
Assyifayufi Khoirul Nisa \\ Universitas Stikubank Semarang \\ assyifakhoirulnisa@gmail.com \\ Sartika Wulandari \\ Universitas Stikubank Semarang \\ sartika.wulan@gmail.com
}

Received: 24 Feb 2021

Revised: 26 April 2021

Accepted: 26 April 2021

\section{Article History:}

Abstract: This study aims to examine the effect of Tax Avoidance and Institutional Ownership on the Cost of Debt in food and beverage sub-sector manufacturing companies listed on the Indonesian Stock Foam for the 2016-2019 Period. The research methodology used is quantitative methods and the data source comes from secondary data obtained from the Indonesia Stock Exchange. The sampling technique used the purposive sampling method with annual data and the research period from 2016 to 2019. The data analysis technique used was multiple linear regression by conducting normality tests, classical assumption tests (multicollinearity test, autocorrelation test, heteroscedasticity test) and hypothesis testing. using the $T$ test to test the partial regression coefficient and the $F$ test to test the significance of the effect together with a significance level of 5\%. The results of this study indicate that partially the independent variables Tax Avoidance and Institutional Ownership have a significant negative effect on the Cost of Debt in the food and beverage sub-sector manufacturing companies listed on the IDX 2016-2019. Meanwhile, simultaneously the independent variables consisting of Tax Avoidance and Institutional Ownership have a significant effect on the Cost of Debt in the food and beverage sub-sector manufacturing companies listed on the IDX 2016-2019

Keywords: Tax Avoidance, Cost of Debt, Institutional Ownership

\section{PENDAHULUAN}

Setiap perusahaan membutuhkan pendanaan dalam mengelola dan mengembangkan bisnis yang dijalankannya guna memperlancar aktifitas operasional perusahaannya. Sumber pendanaan berasal dari dua sumber yaitu pendananaan bersumber dari internal dan juga eksternal. Sumber 
dana internal merupakan sumber dana yang berasal dari dalam perusahaan yang dihasilkan sendiri oleh perusahaan yang dapat berupa laba yang tidak dibagikan atau laba ditahan. Sedangkan sumber dana eksternal yaitu dana yang diperoleh dari luar perusahaan seperti pinjaman (hutang).

Salah satu sumber pendanaan eksternal yang biasa dilakukan adalah dengan menerbitkan surat utang yang nantinya akan dibeli oleh kreditor. Dengan membeli surat utang, kreditor akan mendapatkan imbal hasil berupa bunga. Bagi perusahaan yang berutang, bunga tersebut merupakan pengembalian yang harus diberikan perusahaan pada kreditor. Tingkat pengembalian yang diberikan perusahaan inilah

yang akan menjadi cost of debt (biaya utang) bagi perusahaan (Marcelliana, 2014). Selain mendapatkan imbal hasil (return) berupa bunga, kreditor juga menanggung risiko dari pembelian surat hutang perusahaan. Salah satu jenis risiko yang ditanggung kreditor adalah risiko perusahaan, yaitu risiko terkait karakteristik perusahaan dan cara

manajemen mengelola perusahaan. Return dan risiko merupakan trade-off. Semakin besar kreditor menilai risiko yang dimiliki suatu perusahaan, semakin besar pula bunga yang akan dibebankan pada perusahaan tersebut (Santosa dan Kurniawan, 2016).

Dengan adanya return dan resiko terhadap pembelian surat hutang, maka kreditor perlu memahami secara detail mengenai biaya hutang perusahaan. Dalam pajak, biaya hutang diatur pada PMK No.169/PMK.010/2015. Pengertian hutang menurut PMK No.169/PMK.010/2015 adalah saldo rata-rata pinjaman tiap akhir bulan yang dihitung, baik hutang jangka panjang maupun jangka pendek selain hutang dagang. Adapun modal menurut PMK No.169/PMK.010/2015 adalah jumlah modal yang disetor pada akhir tahun pajak termasuk laba yang tidak dan/atau belum dibagikan. Bunga hutang yang diakui sebagai biaya adalah sebesar bunga atas pinjaman atau hutang yang perbandingannya terhadap modal, yaitu setinggi-tingginya (4:1).

Perusahaan dapat memperkecil pajaknya dengan memanfaatkan deductible expense atau dengan kata lain biaya yang dapat dikurangkan. Salah satu deductible expense yaitu dengan menggunakan bunga hutang yang diakui sebagai biaya. Cost of debt adalah tingkat pengembalian sebelum pajak yang harus dibayar oleh perusahaan ketika melakukan pinjaman. Cost of debt dihitung sebesar beban bunga yang dibayarkan oleh perusahaan dalam periode satu tahun dibagi jumlah rata-rata pinjaman jangka panjang dan jangka pendek yang berbunga selama tahun tersebut. Cost of debt bisa diartikan juga sebagai imbal balik atau return yang diharapkan oleh kreditor atas dana yang dipinjamkan. Cost of debt inilah yang dapat digunakan sebagai biaya pengurang untuk meminimalkan beban pajak perusahaan (Masri dan Martani, 2012). 
Dalam upaya meminimalkan pembayaran pajak yang dibayarkan, perusahaan biasanya melakukan manajemen pajak. Manajemen pajak merupakan salah satu sarana untuk memenuhi kewajiban perpajakan dengan benar, namun jumlah pajak yang dibayar perusahaan dapat ditekan serendah mungkin untuk memperoleh laba dan likuiditas yang diharapkan. Tujuan manajemen pajak dapat dibagi menjadi dua, yaitu dengan cara menerapkan peraturan perpajakan secara benar dan usaha efisiensi untuk mencapai laba dan likuiditas yang seharusnya. Salah satu bentuk manajemen pajak yang dapat dilakukan adalah perencanaan pajak (tax planning). Tax planning yang dilakukan perusahaan dapat dilakukan dengan berbagai strategi, salah satunya adalah penghindaran pajak (tax avoidance) (Suandy, 2016).

Dalam konteks perusahaan, tax avoidance sengaja dilakukan oleh perusahaan untuk memperkecil tingkat pembayaran pajak yang harus dilakukan perusahaan, serta meningkatkan cash flow perusahaan. Sedangkan dalam konteks pendapatan negara, tax avoidance telah membuat negara kehilangan potensi pendapatan pajak yang seharusnya diterima negara untuk mengurangi beban defisit atas anggaran negara (Budiman dan Setiyono, 2012). Selain itu, menurut Masri dan Martani (2012) mengatakan bahwa perusahaan yang melakukan tax avoidance akan mengurangi penggunaan utang, sehingga akan meningkatkan financial slack, mengurangi biaya dan risiko kebangkrutan, meningkatkan kualitas kredit, dampaknya akan mengurangi cost of debt. Dengan kata lain, aktivitas tax avoidance akan menyebabkan turunnya penggunaan hutang yang menyebabkan turunnya risiko perusahaan karena kualitas kredit yang semakin baik. Hal ini mengindikasikan bahwa perusahaan yang melakukan tax avoidance akan menggunakan hutang yang lebih kecil. Maka, semakin besar tax avoidance akan semakin kecil cost of debt yang ditanggung oleh perusahaan.

Selain tax avoidance, terdapat faktor lain yang dapat mempengaruhi cost of debt yaitu kepemilikan institusional. Kepemilikan institusional memiliki kemampuan dalam memonitoring manajemen sehingga dapat mengurangi sikap oportunistik manajemen. Kepemilikan institusional yang besar akan memperbesar pengawasan terhadap manajemen sehingga manajemen akan berusaha untuk bekerja dengan lebih baik dalam melaksanakan pengelolaan perusahaan. Selain itu melalui kepemilikan institusional ini juga akan mengurangi penggunaan hutang oleh manajemen sehingga akan menurunkan biaya utang yang dibebankan pada perusahaan. Adanya kontrol ini akan menyebabkan manajemen menggunakan hutang pada tingkat yang rendah untuk mengantisipasi kemungkinan terjadinya financial distress dan financial risk (Sherly dan Fitria, 2019).

Dengan adanya kepemilikan institusional, monitoring yang efektif terhadap pihak manajemen dapat dilakukan sehingga dapat meningkatkan 
kinerja perusahaan. Sejalan dengan meningkatnya kinerja perusahaan maka risiko yang dimiliki perusahaan juga akan semakin kecil sehingga kreditor dapat memberikan return yang lebih rendah atas sejumlah dana yang dipinjamkan kepada perusahaan. Selain itu dengan semakin tingginya tingkat kepemilikan institusional, terdapat monitoring yang efektif yang dilakukan terhadap manajemen oleh pihak investor institusional yang dapat menyebabkan penggunaan hutang menurun, karena peranan hutang sebagai salah satu alat monitoring biaya keagenan sudah diambil alih oleh investor institusional (Yeniatie dan Destriana, 2010).

Beberapa penelitian telah dilakukan oleh peneliti sebelumnya berkaitan dengan biaya modal dan penghindaran pajak, diantaranya penelitian yang dilakukan oleh Masri \& Martani (2012) menunjukkan bahwa tax avoidance berpengaruh positif terhadap cost of debt. Penelitian yang sama juga sudah dilakukan oleh Marcelliana (2014) dan penelitian tersebut menunjukkan hasil yang konsisten yang menunjukkan bahwa tax avoidance memiliki pengaruh positif terhadap cost of debt. Berbeda dengan hasil penelitian yang dilakukan (Novianti, 2014) yang menunjukkan bahwa tax avoidance tidak berpengaruh positif terhadap cost of debt. Selain itu, penelitian ini juga pernah dilakukan oleh Erniawati (2014) yang menunjukkan hasil bahwa tax avoidance berpengaruh negatif terhadap cost of debt.

Selanjutnya penelitian mengenai kepemilikan institusional dilakukan oleh Yunita (2012) yang menunjukkan bahwa kepemilikan institusional berpengaruh signifikan terhadap biaya hutang. Sedangkan Agustami dan Yunanda (2014) memperoleh hasil bahwa kepemilikan insitusional berpengaruh negatif dengan biaya hutang. Semakin besarnya kepemilikan institusional, maka akan memperbesar control kepada manajemen

sehingga diharapkan kinerja manajemen pun semakin baik. $\mathrm{Hal}$ ini berkaitan dengan biaya hutang yang akan ditanggung oleh perusahaan sebagai tingkat pengembalian yang diminta oleh kreditur.

Pada penelitian ini, objek penelitian yaitu pada perusahaan manufaktur sub sektor makanan dan minuman yang terdaftar di BEI. Peneliti tertarik untuk melakukan penelitian pada perusahaan makanan dan minuman dikarenakan perusahaan tersebut merupakan perusahaan yang menjadi pilihan para investor dalam menginvestasikan dana mereka, dimana dilihat dari perkembangan reaslisasi investasi penanaman modal dalam negeri (PMD) triwulan III 2017 mencapai Rp 27,92 triliun atau meningkat sebesar 16,3 persen dibanding periode yang sama tahun 2016. Sedangkan, untuk

Penanaman modal asing (PMA) sebesar USD 1,46 miliar (http://www.kemenperin.go.id). Oleh karena itu perusahaan manufaktur sub sektor makanan dan minuman merupakan perusahan yang menjanjikan bagi investor untuk berinvestasi. 


\section{Rumusan Masalah}

Berdasarkan latar belakang yang telah diuraikan, maka rumusan masalah dalam penelitian tentang: 1) Pengaruh Tax Avoidance terhadap Cost of Debt pada Perusahaan Sub Sektor Makanan dan Minuman yang terdaftar di Bursa Efek Indonesia 2) Pengaruh Kepemilikan Institusional berpengaruh negative Signifikan terhadap Cost of Debt pada Perusahaan Sub Sektor Makanan dan Minuman yang terdaftar di Bursa Efek Indonesia.

\section{Penelitian Terdahulu}

\section{TINJAUAN PUSTAKA}

Penelitian yang berkaitan dengan cost of debt telah dilakukan di Indonesia dengan variabel yang beragam dan hasil yang berbeda-beda. Pada penelitian ini menganalisis pengaruh tax avoidance dan kepemilikan institusional terhadap cost of debt. Perbedaan pada penelitian ini adalah objek penelitian pada perusahaan sub sektor makanan dan minuman serta tahun penelitian yaitu pada periode 2016-2019.

Peneliti Sherly dan Fitria menunjukkan bahwa penghindaran pajak berpengaruh negatif terhadap biaya hutang. Semakin kecil Cash Effective Tax Rate maka biaya hutang (Cost of Debt) akan semakin besar. Kepemilikan institusional tidak berpengaruh terhadap biaya hutang. Selanjutnya profitabilitas yang diproksikan dengan Return on Assets (ROA) berpengaruh negative terhadap biaya hutang artinya semakin tinggi profitabilitas perusahaan maka perusahaan akan memiliki dana internal yang tinggi yang dapat digunakan dalam pembiayaan sehingga penggunaan hutang semakin kecil yang menyebabkan biaya hutang juga menjadi kecil.

Hasil penelitian yang dilakukan Utama, Kirana, dan Sitanggang (2019) menunjukkan bahwa penghindaran pajak tidak berpengaruh signifikan terhadap biaya hutang, dan kepemilikan institusional tidak dapat memoderasi hubungan antara penghindaran pajak dan biaya hutang.

Penelitian yang dilakukan Santosa dan Kurniawan (2016) Berdasarkan hasil analisis, diperoleh hasil bahwa tax avoidance berpengaruh positif terhadap cost of debt pada perusahaan manufaktur yang terdaftar di Bursa Efek Indonesia (BEI) periode 2010-2014. Kreditor menganggap tax avoidancesebagai praktik yang mengandung risiko sehingga meningkatkan cost of debt. Governance index dan kepemilikan institusional berpengaruh negatif terhadap biaya utang. Ukuran perusahaan berpengaruh positif terhadap biaya utang. Sedangkan kepemilikan manajerial tidak berpengaruh terhadap biaya utang. Saran untuk penelitian selanjutnya dapat menggunakan proksi lain dalam menghitung biaya utang dan menggeneralisasikan perusahaan yang terdaftar sebagai peserta CGPI. 
Hasil penelitian yang dilakukan (Aziza,2016) yang berjudul Pengaruh Penghindaran Pajak terhadap Biaya Hutang dengan Kepemlikan Institusioanl sebagai Variabel Pemoderasi pada Perusahaan Manufaktur yang terdaftar di BEI tahun 2013 - 2015 menunjukkan bahwa variabel penghindaran pajak memiliki pengaruh yang signifikan terhadap biaya hutang. Kepemilikan institusional tidak dapat memoderasi penghindaran pajak terhadap biaya hutang.

\section{Landasan Teoritis dan Hipotesis Penelitian Teori Keagenan (Agency Theory)}

Teori agensi memaparkan hubungan antara prinsipal (pemilik) dengan agen (manajer), pemilik memberikan tanggung jawab atas pengelolaan perusahaan kepada manajer dengan harapan manajer mampu memaksimalkan keuntungan perusahaan dan memenuhi keinginan pemilik. Pada dasarnya setiap pemegang saham menghendaki mendapatkan keuntungan secara maksimal dari perusahaan tempat mereka menanamkan modal. Namun dari sisi manajemen perusahaan juga mengharapkan adanya kompensasi dari perusahaan. Kemungkinan yang terjadi ialah manajer cenderung melakukan praktik yang bertujuan memaksimalkan kepentingan mereka sendiri (Jensen, 1976).

\section{Tax Avoidance}

Tax avoidance didefinisikan sebagai pengaturan transaksi dalam rangka memperoleh keuntungan, manfaat, atau pengurangan pajak dengan cara yang undesirable (tidak diinginkan) oleh peraturan perpajakan. Secara umum, tax avoidance merupakan pengaturan transaksi-transaksi keuangan dengan berbagai cara yang tujuannya adalah untuk mengurangi beban pajak yang harus dibayarkan berdasarkan hukum pajak, sehingga termasuk perbuatan yang tidak melanggar hukum. Secara hukum, penghematan pajak dengan cara ini memang tidak ada larangannya, namun sering mendapat sorotan yang kurang baik dari kantor pajak karena dianggap berkonotasi negatif dan menunjukkan perilaku ketidakpatuhan (Brown, 2012).

Perencanaan pajak merupakan langkah awal dari manajemen pajak yang digunakan untuk mengestimasi jumlah pajak yang akan dibayar dan hal -hal yang dapat dilakukan untuk menghindari pajak dengan cara mengumpulkan dan meneliti peraturan perpajakan, dengan maksud dapat diseleksi jenis tindakan penghematan pajak yang akan dilakukan (Astutik, 2016). Sebuah perusahaan menggunakan berbagai strategi untuk menurunkan pajak yang harus dibayarnya, salah satunya dengan melibatkan jasa konsultan (Huseynov \& Klamm, 2012). Annuar et al. (2014) menyebutkan bahwa manfaat yang paling jelas dari tindakan penghindaran pajak ialah penghematan kas dari pajak yang dihindarkan. Penghematan kas mengarah pada peningkatan arus kas perusahaan yang 
mana perusahaan dapat melakukan investasi menggunakan kas yang dapat dihematnya, sehingga meningkatkan nilai perusahaan dan kekayaan pemegang saham dengan bertambahnya dividen. Begitu pula dengan manajer merasakan pula manfaatnya dengan diberikannya kompensasi atas manajemen pajak efektif.

\section{Kepemilikan Institusional}

Kepemilikan institusional merupakan kepemilikan saham oleh pihak institusi lain, yaitu kepemilikan oleh perusahaan lain, bank, dan institusi lainnya. Tingkat

kepemilikan institusional yang tinggi dapat memberikan pengawasan lebih besar yang dilakukan oleh pihak investor institusional, sehingga dapat meminimalkan tingkat penyelewengan yang dilakukan oleh pihak manajemen yang dapat menurunkan nilai

Perusahaan (Jensen dan Meckling, 1976). Menurut Riduwan (2013) kepemilikan institusional memiliki peranan yang sangat penting dalam meminimalisasi konflik keagenan yang terjadi antara manajer dan pemegang saham. Keberadaan investor institusional dianggap mampu menjadi mekanisme monitoring yang efektif dalam setiap keputusan yang diambil oleh manajer. Hal ini disebabkan investor institusional terlibat dalam pengambilan yang strategis sehingga tidak mudah percaya terhadap tindakan manipulasi laba.

Kepemilikan Institusional merupakan persentase saham yang dimiliki oleh pihak institusi seperti perusahaan reksa dana, asuransi, bank, dan sebagainya. Adanya kepemilikan saham oleh institusi lain dapat mendorong peningkatan pengawasan yang lebih optimal, mekanisme monitoring tersebut akan mendisiplinkan pengunaan debt (utang) dalam struktur modal dan menjamin peningkatan kemakmuran pemegang saham (Sofyaningsih \& Hardiningsih, 2011). Semakin besar prosentase saham yang dimiliki investor institusional akan menyebabkan pengawasan yang dilakukan menjadi lebih efektif karena dapat mengendalikan perilaku oportunistik manajer dan mengurangi agency cost (Candradewi dan Sedana, 2016).

\section{Cost of Debt}

Biaya utang adalah tingkat pengembalian yang dibutuhkan oleh kreditur saat melakukan pendanaan dalam suatu perusahaan. Biaya Utang (cost of debt) sebagai tingkat pengembalian yang diinginkan kreditur saat memberikan pendanaan kepada perusahaan (Masri, 2010).

Dalam PSAK No. 26 (Revisi 2018), biaya pinjaman adalah bunga dan biaya lain yang ditanggung entitas sehubungan dengan peminjaman dana. Biaya pinjaman meliputi antara lain bunga atas penggunaaan dana pinjaman baik pinjaman jangka panjang maupun jangka pendek, 
amortisasi atas biaya yang terkait dengan perolehan pinjaman seperti konsultan, ahli hukum, commitment fee, dan selisih kurs atas pinjaman dalam valuta asing (sepanjang selisih kurs tersebut merupakan penyesuaian terhadap biaya bunga) atau amortisasi premi kontrak valuta berjangka panjang dalam rangka hedging dana yang dipinjam dalam valuta asing.

Perusahaan memiliki beberapa alternatif dalam melakukan pendanaan. Pada umumnya sumber pendanaan perusahaan terdiri dari utang dan ekuitas atau saham. Fokus penelitian ini adalah sumber pendanaan perusahaan dimana salah satunya adalah dengan menggunakan utang. Utang merupakan salah satu cara memperoleh dana dari pihak eksternal yaitu kreditur. Dana yang diberikan oleh kreditur hal pendanaan terhadap perusahaan tersebut menimbulkan biaya utang bagi perusahaan, dimana biaya utang (cost of debt) merupakan tingkat bunga yang diterima oleh kreditur sebagai tingkat pengembalian yang diisyaratkan (Yunita, 2012).

\section{Hipotesis Penelitian \\ Pengaruh Penghindaran Pajak (Tax Avoidance) terhadap Biaya Hutang (Cost of Debt)}

Perilaku penghindaraan pajak merupakan upaya yang dilakukan oleh perusahaan untuk meminimalisasi pembayaran pajak dengan menggunakan hutang, dan secara hukum diperbolehkan. Di dalam pengelolaan sumber pendanaan perusahaan memiliki berbagai alternatif, salah satunya melakukan pinjaman dari kreditor. Perusahaan yang menggunakan hutang dinilai memiliki nilai yang lebih tinggi dibandingkan dengan perusahaan yang tidak menggunakan hutang. Hutang akan mendatangkan biaya hutang yang dapat digunakan sebagai tax shield berupa pengurangan pajak yang akan berdampak pada peningkatan nilai perusahaan. Di sisi lain penggunaan hutang ini mendatangkan risiko bagi perusahaan, dan ukuran dari biaya hutang ini merupakan informasi sebagai indikasi adanya risiko. Perusahaan yang melakukan penghindaran pajak dipandang sebagai kreditor sebagai tindakan yang berisiko sehingga akan meningkatkan biaya hutang dari perusahaan (Mardiasmo, 2016: 38).

Hal tersebut didukung dengan penelitian yang dilakukan oleh Santosa dan Kurniawan (2016) yang menyatakan bahwa penghindaran pajak (tax avoidance) berpengaruh positif terhadap biaya hutang.

\section{H1: Penghindaran Pajak (Tax Avoidance) berpengaruh positif terhadap Biaya Hutang (Cost of Debt)}

\section{Pengaruh Kepemilikan Institusional terhadap Biaya Hutang (Cost of Debt)}

Kepemilikan institusional mempunyai peranan yang penting dalam memonitor aktivitas manajemen. Pemegang saham yang lebih besar 
mempunyai dorongan yang besar pula untuk mengawasi kinerja perusahaan untuk digunakan pihak-pihak yang berkepentingan. Berdasarkan sudut pandang teori keagenan, kepemilikan institusional dapat mempengaruhi hubungan antara penghindaran pajak dan biaya hutang (Kholbadalov, 2012). Selain itu kepemilikan institusional ini juga mempunyai pengaruh yang negatif pada biaya hutang sehingga mengurangi biaya agensi yang dapat mengurangi perilaku oportunistik dari manajer. Semakin besar kepemilikan institusional maka semakin efisien fungsi monitoring terhadap manajemen dalam pemanfaatan asset perusahaan serta pencegahan pemborosan oleh manajemen (Sofyaningsih dan Hardiningsih, 2011). Berdasarkan penjelasan tersebut, maka hipotesis kedua yang ndibangun dalam penelitian ini yaitu:

\section{H2: Kepemilikan Institusional berpengaruh negatif terhadap Biaya Hutang (Cost of Debt)}

\section{Pengaruh Penghindaran Pajak (Tax Avoidance) terhadap Biaya Hutang (Cost of Debt) Melalui Kepemilikan Institusional}

Perusahaan yang menggunakan hutang dinilai memiliki nilai yang lebih tinggi dibandingkan dengan perusahaan yang tidak menggunakan hutang. Hutang akan mendatangkan biaya hutang yang dapat digunakan sebagai untuk pengurangan pajak yang akan berdampak pada peningkatan nilai perusahaan. Di sisi lain penggunaan hutang ini mendatangkan risiko bagi perusahaan, dan ukuran dari biaya hutang ini merupakan informasi sebagai indikasi adanya risiko. Perusahaan yang melakukan penghindaran pajak dipandang sebagai kreditor sebagai tindakan yang berisiko sehingga akan meningkatkan biaya hutang dari perusahaan. Kepemilikan institusional mempunyai peranan yang penting dalam memonitor aktivitas manajemen. Pemegang saham yang lebih besar mempunyai dorongan yang besar pula untuk mengawasi kinerja perusahaan untuk digunakan pihak-pihak yang berkepentingan. Berdasarkan sudut pandang teori keagenan, kepemilikan institusional dapat mempengaruhi

Hubungan antara penghindaran pajak dan biaya hutang. Hal tersebut didukung dengan penelitian yang dilakukan oleh Santosa \& Kurniawan (2016) yang menyatakan bahwa

penghindaran pajak (tax avoidance) berpengaruh terhadap biaya hutang dan kepemilikan institusional berpengaruh terhadap biaya hutang. 


\section{H3 : Penghindaraan pajak berpengaruh positif terhadap biaya hutang melalui kepemilikan institusional.}

\section{Kerangka Konsep Penelitian}

Berdasarkan penjelasan diatas disusun kerangka pemikiran sebagai berikut:

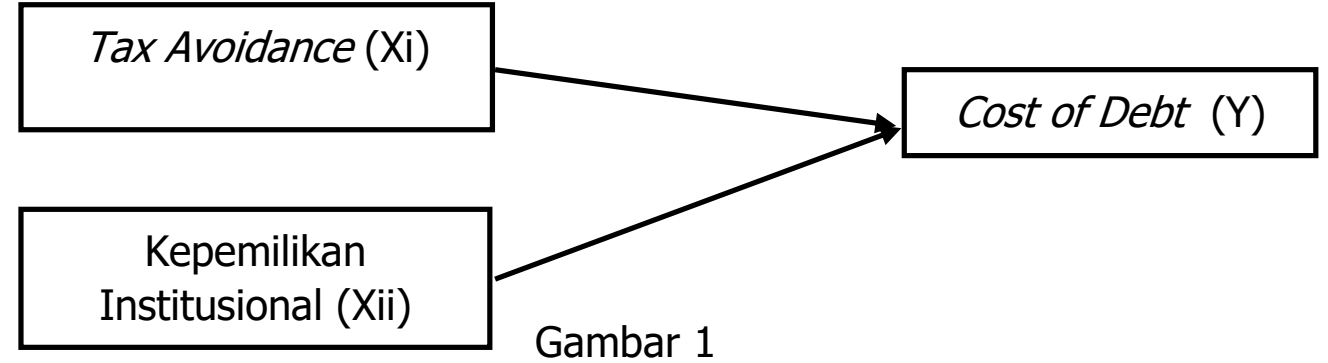

Kepemilikan Institusional diantara Tax Avoidance dan Cost of Debt

\section{Jenis Penelitian}

\section{METODE PENELITIAN}

Dalam penelitian ini, desain penelitian yang digunakan adalah asosiatif dengan pendekatan kuantitatif. Menurut Sugiyono (2016:11) menyatakan bahwa penelitian asosiatif bertujuan untuk mengetahui pengaruh ataupun hubungan antara dua variabel atau lebih. Penelitian ini bertujuan untuk mengetahui pengaruh antara variabel independenppenghindaran pajakkk(tax avoidance)pdan kepemilikankkinstitusional terhadapppbiaya modalp(cost of debt) padappperusahaan manufakturggsub sektormmmakanan danbmminuman yangkkterdaftar dikBursa EfekkIndonesiappada tahunm2016-2019.

\section{Populasi dan Sampel}

Populasi dalam penelitian ini adalah seluruh perusahaan manufaktur sub sektor makanan dan minuman yang terdaftar di Bursa Efek Indonesia. Metode pemilihan sampel yang digunakan dalam penelitian ini adalah metode purposive sampling, yaitu tipe pemilihan sampel secara tidak acak yang informasinya diperoleh dengan menggunakan pertimbangan tertentu (Sugiyono, 2016:117). Adapun kriteria-kriteria pengambilan sampel dalam penelitian ini adalah:

1. Perusahaan manufaktur sub sektor makanan dan minuman yang terdaftar di Bursa Efek Indonesia yang terdaftar di BEI tahun 20162019.

2. Menerbitkan laporan keuangan yang telah di audit pada tahun 20162019.

3. Perusahaan memiliki beban bunga.

4. Perusahaan mempunyai laba pada tahun 2016-2019.

5. Perusahaan memiliki struktur kepemilikan yang lengkap. 


\section{Jenis dan Sember Data}

Data yang digunakan dalam penelitian ini adalah data sekunder yang diperoleh dari laporan keuangan perusahaan manufaktur sub sektor makanan dan minuman yang terdaftar di Bursa Efek Indonesia (BEI) tahun 2016-2019 yang diambilkkdari websiteppresmi bursappefek indonesiappyaitu www.idx.co.id. Dalam memperoleh informasi dan data yang akan digunakan pada penelitian ini, maka pengumpulan data dilakukan dengan cara Dokumentasi. Dokumentasi merupakan proses pengumpulan data yang dapat digunakan dengan cara melakukan penelusuran terhadap dokumen-dokumen pendukung penelitian, studi dokumentasi dilakukan dengan mengumpulkan data sekunder yang diperoleh dari Bursa Efek Indonesia serta dari website resmi Bursa Efek Indonesia www.idx.co.id kemudian mencatat, menyalin, dan menggandakan data-data informasi yang meliputi beban pajak tangguhan, laba perusahaan, dan biaya hutang yang dibebankan pada perusahaan yang tertera dalam laporan keuangan perusahaan serta data lainnya yang dibutuhkan dalam penelitian ini.

\section{Hasil Bahasan}

\section{Hasil Uji Asumsi Klasik Uji Normalitas}

Uji Normalitas merupakan bentuk pengujian yang bertujuan untuk melihat apakah nilai residual terdistribusi normal atau tidak. Model persamaan regresi yang baik adalah memiliki nilai residual yang terdistribusi normal. Uji yang digunakan untuk mendeteksi data terdistribusi normal dapat menggunakan uji normalitas One-Sample Kolmogorov-Smirnov Test. Berikut ini adalah hasil uji normalitas OneSample Kolmogorov-Smirnov Test hasil nilai Asymp. sig sebesar 0,200 > 0,05 ; sehingga dapat disimpulkan bahwa data penelitian terdistribusi normal.

\section{Uji Multikolonearitas}

Hasil penelitian menunjukkan semua variabel independen yang terdiri dari Tax Avoidance dan kepemilikan institusional memiliki nilai tolerance lebih besar dari 0,1 (tolerance> 0,1). Hasil perhitungan menunjukkan bahwa kedua variabel independen memiliki nilai VIF lebih kecil daripada 10,0 (VIF < 10,0). Dimana Tax Avoidance memiliki nilai tolerance sebesar 0,972 >0.1 dan nilai VIF sebesar 1,028<10,00. Kepemilikan institusional memiliki nilai tolerance sebesar 0,972 >0.1 dan nilai VIF sebesar $1,028<10,00$. Oleh karena itu, dapat disimpulkan bahwa hasil pengujian telah memenuhi asumsi klasik dan tidak terdapat multikolinearitas diantara variabel independen dalam model regresi. 


\section{Uji Autokorelasi}

Berdasarkan hasil uji autokorelasi menggunakan uji Durbin Watson yang terdapat pada tabel 4.6, menunjukkan hasil bahwa nilai d (DW-test) adalah sebesar 2,184. Nilai dw lebih besar daripada nilai dU sebesar 1,6751 dan lebih kecil daripada nilai (4-dU atau 4-1,6751) sebesar 2,3249 sehingga dapat disimpulkan bahwa tidak terdapat autokorelasi dalam model regresi pada penelitian ini.

\section{Uji Heteroskedastisitas}

Berdasarkan pengujian heteroskedasitas dengan uji glister pada tabel di atas hasil menunjukkan bahwa semua variabel independen memiliki nilai signifikansi $>0,05$ (sig $>0,05$ ) sehingga dapat disimpulkan bahwa data tidak terindikasi adanya heterokedastisitas pada variabel independen.

\section{Hasil Pengujian Hipotesis \\ Model Regresi Linier Berganda}

Penelitian ini menggunakan model regresi berganda, dimana dalam persamaan mengandung tiga variabel independen, tiga variabel independen tersebut adalah Cos of debt, Tax Avoidance dan Kepemilikan Institusional. Hasil analisis regresi sederhana dapat dilihat pada tabel 4.7 berikut.

Tabel 1 Hasil Analisis Berganda

\begin{tabular}{|c|c|c|c|c|c|c|}
\hline \multirow{2}{*}{\multicolumn{2}{|c|}{ Model }} & \multicolumn{2}{|c|}{$\begin{array}{c}\text { Unstandardized } \\
\text { Coefficients }\end{array}$} & \multirow{2}{*}{\begin{tabular}{|c|}
$\begin{array}{c}\text { Standardize } \\
\text { d } \\
\text { Coefficients }\end{array}$ \\
Beta \\
\end{tabular}} & \multirow[b]{2}{*}{$\mathrm{t}$} & \multirow[b]{2}{*}{ Sig. } \\
\hline & & $\mathrm{B}$ & Std. Error & & & \\
\hline \multirow[t]{3}{*}{1} & (Constant) & .042 & .013 & & 3.292 & .002 \\
\hline & Tax Avoidance & -.064 & .031 & -.218 & -2.086 & .041 \\
\hline & Kepemilikan Institusional & -.101 & .021 & -.503 & -4.799 & .000 \\
\hline
\end{tabular}

\section{Uji Signifikansi Parameter Individual (Uji Statistik t)}

Pada tabel diatas yang diinterpretasikan adalah nilai dalam kolom B, baris pertama menunjukkan konstanta (a) dan baris selanjutnya menunjukkan konstanta berdasarkan tabel di atas, maka persamaan regresi yang dapat dibentuk adalah sebagai berikut:

Dimana:

$$
Y=3,292-2,086 X_{1}-4,799 X_{2}+e
$$

$\begin{array}{ll}\mathrm{Y} & =\text { Cost Of Debt } \\ \mathrm{X}_{1} & =\text { Tax Avoidance } \\ \mathrm{X}_{2} & =\text { Kepemilikan Institusional } \\ e & =\text { error }\end{array}$


Adapun penjelasan Persamaan model regresi di atas dapat diuraikan sebagai berikut:

1. Nilai konstanta sebesar 3,292 menunjukkan bahwa apabila variabel Tax Avoidance dan kepemilikan institusional bernilai nol (0), maka Cost Of Debt akan sebesar 3,292.

2. Tax Avoidance mempunyai koefisien regresi sebesar -2,086. Hal ini menunjukkan bahwa apabila diasumsikan variabel konstan maka setiap kenaikan Tax Avoidance sebesar satu satuan maka Cost of Debt akan mengalami penurunan sebesar --2,086.

3. Kepemilikan institusional mempunyai koefisien regresi sebesar -4,799. Hal ini menunjukkan bahwa apabila diasumsikan variabel konstan maka setiap kenaikan kepemilikan institusional sebesar satu satuan maka Tax Avoidance akan mengalami penurunan sebesar 4,799.

\section{Uji Koefisien Determinasi $\left(\mathbf{R}^{2}\right)$}

Koefisien determinasi ( $R 2$ ) untuk mengukur seberapa jauh kemampuan model dalam menerangkan variasi variabel dependen.Nilai koefisien determinasi adalah antara nol dan satu.Nilai yang mendekati satu berarti variabel-variabel independen memberikan hampir semua informasi yang dibutuhkan untuk memprediksi variasi variabel dependen (Ghozali, 2005:83).

Tabel 2 Hasil Uji Koefisien Determinasi

\begin{tabular}{|l|r|r|r|r|c|}
\hline Model & \multicolumn{1}{|c|}{$\mathrm{R}$} & $\mathrm{R}$ Square & $\begin{array}{c}\text { Adjusted R } \\
\text { Square }\end{array}$ & $\begin{array}{c}\text { Std. Error of } \\
\text { the Estimate }\end{array}$ & $\begin{array}{c}\text { Durbin- } \\
\text { Watson }\end{array}$ \\
\hline 1 & $.14^{\mathrm{a}}$ & .764 & .743 & .0344953 & 2.184 \\
\hline
\end{tabular}

a. Dependen variabel: Tax Avoidance

b. Predictors: (Constant), Cos of Debt, Kepemilikan Institusional

Uji regresi pada tabel diatas menghasilkan nilai $\mathrm{R}^{2}=0,764$ atau 76,4 persen $(0,764 \times 100$ persen). Hal ini berarti bahwa variabel-variabel bebas (independen) dalam penelitian ini yang terdiri dari Tax Avoidance dan Kepemilikan Institusional dapat menjelaskan sebesar 76,4 persen terhadap variabel terikat (dependen) Cost Of Debt. Sedangkan selebihnya 23,6 persen dapat dijelaskan oleh variabel-variabel lain diluar model yang tidak dimasukkan dalam penelitian ini. 


\section{Uji Normalitas}

Untuk menguji normalitas, dapat menganalisis nilai Kolmogorov Smirnov Test. Dasar pengambilan keputusan adalah, jika nilai probabilitas $>0,05$, maka model regresi memenuhi asumsi normalitas, maka model regresi memenuhi asumsi normalitas dan sebaliknya

Berikut ini adalah hasil uji normalitas, yaitu :

\begin{tabular}{|c|c|c|c|}
\hline Variabel & Sig. & Nilai Kritis & Keterangan \\
\hline $\begin{array}{c}\text { Residual } \\
1\end{array}$ & 0,116 & 0,05 & Normalitas \\
\hline $\begin{array}{c}\text { Residual } \\
2\end{array}$ & 0,434 & 0,05 & Normalitas \\
\hline
\end{tabular}

Berdasarkan hasil uji normalitas dengan Kolmogorov Smirnov Test di atas terlihat bahwa nilai probabilitas $=0,116$ dan 0,434 $>0,05$, maka model regresi memenuhi asumsi normalitas.

\section{Hasil Pengujian Multikolinieritas}

Uji Multikolonieritas bertujuan untuk menguji apakah model regresi ditemukan adanya korelasi antar variable bebas (independen). Hasil perhitungan nilai tolerance menunjukkan tidak ada variable independen yang memiliki nilai tolerance kurang dari 0,10 yang berarti tidak terjadi kolerasi antar variable independen. Hasil perhitungan nilai Variance Inflation Factor (VIF) juga tidak melebihi 10 menunjukkan tidak ada korelasi antar variable independen.

\section{Hasil Pengujian Heterokedastisitas}

Uji Heterokedastisitas bertujuan untuk menguji apakah dalam model regresi terdapat ketidaksamaan varian residual dari suatu pengamatan ke pengamatan yag lain

Hasil uji heterokedastisitas terlihat bahwa tak satupun variabel independen dalam model regresi secara statistik signifikan berhubungan dengan residual. Keenam nilai signifikan antara variable dependen dengan absolute residual lebih besar daripada level 0,05 (a > 0,05) maka tidak terdapat gejala heteroskedastisitas.

\section{Hasil pengujian Autokorelasi}

Uji Autokorelasi bertujuan menguji apakah daam model regresi linear ada korelasi antara kesalahan pengganggu pada periode $\mathrm{t}$ dengan kesalahan pengganggu pada periode t-1 (Ghozali, 2016). Hasil uji autokorelasi terlihat nilai dw sebesar 2,189 dan 2,287 lebih dari du 1,641 dan kurang dari 4-du 2,359. Hasil tersebut menunjukkan penelitian ini tidak terjadi autokorelasi. 


\section{Uji Signifikasi Simultan (Uji Statistik F)}

Berdasarkan hasil olah data diperoleh nilai Sig.F $=0,000<$ Level of Significant $=0,05$, maka Ho ditolak atau Ha diterima, artinya disimpulkan bahwa Tax Avoidance (X1) dan Kepemilikan Institusional (X2) secara bersama-sama berpengaruh signifikan terhadap Cost of Debt $(Y)$.

\section{Uji Hipotesis (Uji t)}

Uji t digunakan untuk membuktikan pengaruh Tax Avoidance (X1) dan Kepemilikan Institusional (X2) terhadap Cost of Debt (Y) secara individual (uji $t$ ) dengan asumsi bahwa variabel yang lain tetap atau konstan. Berdasarkan hasil perhitungan dengan menggunakan program statistik komputer SPSS for Windows diperoleh hasil sebagai berikut:

\begin{tabular}{|c|c|c|}
\hline Variabel & $\begin{array}{c}\text { t- } \\
\text { statistik }\end{array}$ & Sig. \\
\hline $\mathrm{X} 1$ & 4,487 & 0,000 \\
\hline $\mathrm{X} 2$ & $-2,060$ & 0,044 \\
\hline
\end{tabular}

1) Pengujian Pengaruh Tax Avoidance (X1) terhadap Cost of Debt $(Y)$

Berdasarkan hasil olah data diperoleh nilai Sig.t $=0,000<$ Level of Significant $=0,05$, maka $\mathrm{Ho}$ ditolak atau $\mathrm{Ha}$ diterima, artinya disimpulkan bahwa ada pengaruh positif dan signifikan Tax Avoidance (X1) terhadap Cost of Debt (Y).

2) Pengujian Pengaruh Kepemilikan Institusional (X2) terhadap Cost of $\operatorname{Debt}(Y)$

Berdasarkan hasil olah data diperoleh nilai Sig.t $=0,044<$ Level of Significant $=0,05$, maka Ho ditolak atau Ha diterima, artinya bahwa ada pengaruh positif dan signifikan Kepemilikan Institusional (X2) terhadap Cost of Debt (Y).

Uji t digunakan untuk membuktikan pengaruh Tax Avoidance (X1) terhadap Cost of Debt $(Y)$ yang dimediasi oleh Kepemilikan Institusional (X2). Berdasarkan hasil olah data diperoleh koefisien regresi pengaruh langsung ( $X 1$ terhadap $Y$ ) sebesar 0,663 , koefisien regresi pengaruh tidak langsungnya, yaitu 28,685 (X1 ke X2) x 0,007 (X2 ke Y) =0,201. Oleh karena koefisien pengaruh tidak langsung lebih kecil dari koefisien pengaruh langsung, maka dapat disimpulkan bahwa pengaruh yang sebenarnya adalah pengaruh langsung dengan kata lain Tax Avoidance (X1) berpengaruh terhadap Cost of Debt $(Y)$ tidak melalui Kepemilikan Institusional (X2).

\section{Interpretasi Hasil (Pembahasan Hipotesis)}

\section{Pengaruh Tax Avoidance (X1) terhadap Cost of Debt (Y)}

Hasil analisis regresi linier berganda menunjukkan bahwa Tax Avoidance (X1) berpengaruh positif dan signifikan terhadap Cost of Debt 
(Y). Hal ini berarti, jika Tax Avoidance (X1) mengalami peningkatan, maka Cost of Debt (Y) juga akan mengalami peningkatan. Hal tersebut didukung dengan penelitian yang dilakukan oleh Santosa \& Kurniawan (2016); Masri \& Martani (2012); Marcelliana (2014); Erniawati (2014) yang menyatakan bahwa penghindaran pajak (tax avoidance) berpengaruh positif terhadap biaya hutang. Perilaku penghindaraan pajak merupakan upaya yang dilakukan oleh perusahaan untuk meminimalisasi pembayaran pajak dengan menggunakan hutang, dan secara hukum diperbolehkan. Dalam pengelolaan sumber pendanaan perusahaan memiliki berbagai alternatif, salah satunya melakukan pinjaman dari kreditor. Perusahaan yang menggunakan hutang dinilai memiliki nilai yang lebih tinggi dibandingkan dengan perusahaan yang tidak menggunakan hutang. Hutang akan mendatangkan biaya hutang yang dapat digunakan sebagai tax shield berupa pengurangan pajak yang akan berdampak pada peningkatan nilai perusahaan. Di sisi lain penggunaan hutang ini mendatangkan risiko bagi perusahaan, dan ukuran dari biaya hutang ini merupakan informasi sebagai indikasi adanya risiko. Perusahaan yang melakukan penghindaran pajak dipandang sebagai kreditor sebagai tindakan yang berisiko sehingga akan meningkatkan biaya hutang dari perusahaan.

\section{Pengaruh Kepemilikan Institusional (X2) terhadap Cost of Debt (Y)}

Hasil analisis regresi linier berganda menunjukkan bahwa Kepemilikan Institusional (X2) berpengaruh negatif dan signifikan terhadap Cost of Debt (Y). Hal ini berarti, jika Kepemilikan Institusional (X2) mengalami peningkatan, maka Cost of Debt (Y) juga akan mengalami penurunan. Hal tersebut didukung dengan penelitian yang dilakukan oleh Santosa \& Kurniawan (2016); Yunita (2012); Agustami \& Yunanda (2014) yang menyatakan bahwa kepemilikan institusional berpengaruh negatif terhadap biaya hutang. Kepemilikan institusional mempunyai peranan yang penting dalam memonitor aktivitas manajemen. Pemegang saham yang lebih besar mempunyai dorongan yang besar pula untuk mengawasi kinerja perusahaan untuk digunakan pihak-pihak yang berkepentingan. Berdasarkan sudut pandang teori keagenan, kepemilikan institusional dapat mempengaruhi hubungan antara penghindaran pajak dan biaya hutang (Kholbadalov, 2012). Selain itu kepemilikan institusional ini juga mempunyai pengaruh yang negatif pada biaya hutang, sehingga mengurangi biaya agensi yang dapat mengurangi perilaku oportunistik dari manajer. Semakin besar kepemilikan institusional, maka semakin efisien fungsi monitoring terhadap manajemen dalam

pemanfaatan asset perusahaan serta pencegahan pemborosan oleh manajemen (Sofyaningsih \& Hardiningsih, 2011). 


\section{Pengaruh Tax Avoidance (X1) terhadap Cost of Debt (Y) melalui Kepemilikan Institusional (X2)}

Hasil analisis jalur diperoleh koefisien regresi pengaruh langsung (X1 terhadap $Y$ ) sebesar 0,663 , koefisien regresi pengaruh tidak langsungnya, yaitu 28,685 (X1 ke X2) x 0,007 (X2 ke Y) =0,201. Oleh karena koefisien pengaruh tidak langsung lebih kecil dari koefisien pengaruh langsung, maka dapat disimpulkan bahwa pengaruh yang sebenarnya adalah pengaruh langsung dengan kata lain Tax Avoidance (X1) berpengaruh terhadap Cost of Debt $(Y)$ tidak melalui Kepemilikan Institusional (X2). Hal ini berarti, Tax Avoidance (X1) berpengaruh langsung terhadap Cost of Debt $(Y)$. Hal tersebut didukung dengan penelitian yang dilakukan oleh Santosa \& Kurniawan (2016); Masri \& Martani (2012); Marcelliana (2014); Erniawati (2014) yang menyatakan bahwa Tax Avoidance berpengaruh langsung terhadap biaya hutang. Perusahaan yang menggunakan hutang dinilai memiliki nilai yang lebih tinggi dibandingkan dengan perusahaan yang tidak menggunakan hutang. Hutang akan mendatangkan biaya hutang yang dapat digunakan sebagai tax shield berupa pengurangan pajak yang akan berdampak pada peningkatan nilai perusahaan. $\mathrm{Di}$ sisi lain penggunaan hutang ini mendatangkan risiko bagi perusahaan, dan ukuran dari biaya hutang ini merupakan informasi sebagai indikasi adanya risiko. Perusahaan yang melakukan penghindaran pajak dipandang sebagai kreditor sebagai tindakan yang berisiko sehingga akan meningkatkan biaya hutang dari perusahaan. Kepemilikan institusional mempunyai peranan yang penting dalam memonitor aktivitas manajemen. Pemegang saham yang lebih besar mempunyai dorongan yang besar pula untuk mengawasi kinerja perusahaan untuk digunakan pihak-pihak yang berkepentingan. Berdasarkan sudut pandang teori keagenan, kepemilikan institusional dapat mempengaruhi hubungan antara penghindaran pajak dan biaya hutang.

\section{KESIMPULAN DAN SARAN \\ Simpulan}

Berdasarkan hasil penelitian yang telah di uraikan pada bab sebelumnya, dapat ditarik kesimpulan sebagai berikut:

1. Tax Avoidance berpengaruh negatif dan signifikan terhadap Cost of Debt pada perusahaan manufaktur sub sektor makanan dan minuman yang terdaftar di BEI 2016 - 2019.

2. Kepemilikan Institusional berpengaruh negatif dan signifikan terhadap Cost of Debt pada perusahaan manufaktur sub sektor makanan dan minuman yang terdaftar di BEI 2016 - 2019.

3. Tax Avoidance dan Kepemilikan Institusional secara bersama-sama berpengaruh positif dan signifikan terhadap Cost of Debt pada 
perusahaan manufaktur sub sektor makanan dan minuman yang terdaftar di BEI 2016 - 2019.

\section{Saran}

Saran untuk penelitian selanjutnya diharapkan dapat melengkapi keterbatasan penelitian dengan mengembangkan beberapa hal antara lain:

1. Penelitian selanjutnya diharapkan dapat menambah sampel penelitian dan menggunakan perusahaan yang terdaftar di BEI lainnya selain sub sektor makanan dan minuman.

2. Penelitian selanjutnya diharapkan memperpanjang periode pengamatan, agar dapat melihat pengaruh tax avoidance dan kepemilikan institusional terhadap cost of debt dari waktu yang cukup panjang.

3. Perlu mempertimbangkan model berbeda yang akan digunakan dalam penelitian tentang cost of debt dan adanya penambahan variabel yang mungkin berpengaruh terhadap cost of debt seperti corporate governance, kepemilikan saham manejerial, ukuran perusahaan dan variabel yang lainnya

\section{DAFTAR PUSTAKA}

Agustami, Silvana., dan Yunanda, Anggun Cahyani. (2014). Pengaruh Kepemilikan Institusional dan Pengungkapan Sukarela terhadap Biaya Hutang. Jurnal Ekonomi dan Bisnis, Vol. 2, No. 2, Universitas Pendidikan Indonesia.

Candradewi, Intan dan Sedana, Ida B.P. 2016. Pengaruh Kepemilikan Manajerial , Kepemilikan Institusional dan Dewan Komisaris Independen terhadap Return on Asset. E-Jurnal Manajemen Unud, Vol. 5, No. 5, 2016: 3163 - 3190

Erniawati, Ika 2014. Analisis Pengaruh Tax Avoidance Terhadap Biaya Utang dan Kepemilikan Institusional, Naskah Publikasi Universitas Muhamadiyah Surakarta.

Hanlon, Michelle dan Heitzman, Shane. (2010). A Review of Tax Research. Journal of Accounting and Economics. No. 50, Hal. 127-178.

Jensen, Michael C. \& W.H. Meckling. (1976). Theory of the Firm: managerial Behavior, Agency Cost and Ownership Structure. Journal of Financial Economics. 3. Page. 305-360.

Kementrian Perindustrian Republik Indonesia. 2017. Pengaruh Penghindaran Pajak, Kepemilikan Institusional , dan Profitabilitas terhadap Biaya Hutang.

Kholbadalov, U. 2012. The Relationship of Corporate Tax Avoidance, Cost of Debt and Institutional Ownership: Evidence from Malaysia, Atlantic Review of Economics, 2nd. 
Marcelliana, E. (2014). Pengaruh Tax Avoidance Terhadap Cost Of Debt pada Perusahan Manufaktur yang Terdaftar Di Bursa Efek Indonesia Periode 2010-2012. Jurnal MODUS Vol. 2 No. 3, 139-154.

Mardiasmo. 2016. Perpajakan Edisi Revisi Tahun 2016. Yogyakarta: Penerbit Andi.

Masri, Indah dan Dwi Martani. 2012. Pengaruh Tax avoidance Terhadap Cost of debt. Simposium Nasional Akuntansi XV, hal. 1 - 28, Universitas Indonesia.

Masri, Indah. 2010. Pengaruh Tax Avoidance terhadap Cost of Debt . Jakarta: Simposium Nasional Akuntansi XV (Banjarmasin).

Novianti, Arti Resha. (2014). Pengaruh Penghindaran Pajak terhadap Biaya Hutang (Studi Kasus pada Perusahaan Manufaktur yang Terdaftar di Bursa Efek Indonesia pada tahun 2010-2012). Published Skripsi. Universitas Pendidikan Indonesia, Bandung.

Peraturan Menteri Keuangan Nomor. 169/PMK.010/2015 tentang penentuan besarnya perbandingan antara Hutang dan Modal perusahaan untuk keperluan perhitungan Pajak Penghasilan.

Pittman, J., Fortin, S., (2004). Auditor choice and the cost of debt capital for newly public firms.Journal of Accounting and Economics 37, 113136.

PSAK No. 26 Tahun 2018 Tentang Biaya Pinjaman.

Riduwan, S. 2013. Pengaruh Corporate Governance terhadap Nilai Perusahaan: Kualitas Laba sebagai Variabel Intervewing, Jurnal Ilmu dan Riset Akuntansi, 1 (1).

Santosa, J. E. dan Kurniawan, Heni. 2016. Analisis Pengaruh Tax Avoidance Terhadap Cost of Debt Pada Perusahaan Manufaktur Yang Terdaftar Di BEI Selama Periode 2010-2014. MODUS Vol. 28 (2). Universitas Atma Jaya. Yogyakarta.

Sherly, Elvis Nopriyanti dan Fitria, Desi. (2019). Pengaruh Penghindaran Pajak, Kepemilikan Institusional, dan Profitabilitas terhadap Biaya Hutang. (Studi Empiris pada Perusahaan Manufaktur yang terdaftar di BEI Periode 2011-2015). Jurnal Ekombis Review, Vol. 7, No. 1, Universitas Muhammadiyah Bengkulu.

Sofyaningsih, S., dan P. Hardiningsih. 2011. "Struktur Kepemilikan, Kebijakan Deviden, Kebijakan Utang dan Nilai Perusahaan ". Dinamika Keuangan dan Perbankan, Vol. 3, No. 1, hlm: 68-87.

Suandy, E. 2016. Perencanaan Pajak : Edisi ke 6. Jakarta: Salemba Empat Sugiyono. 2016. Metode Penelitian Kuantitatif, Kualitatif dan R\&D. Bandung: PT Alfabet.

Yunita, Nancy. 2012. Pengaruh Corporate Governance, terhadap Voluntary Disclosure dan Biaya Hutang. Jurnal Ilmiah Mahasiswa Akuntansi, Vol. 1, No. 1. 